\title{
ANALYSIS OF TWO GROUPS OF PLANE INFANTRY TARGETS AS SETS OF GEOMETRIC PRIMITIVES
}

\author{
Vadim L. Khaikov \\ independent researcher, Krasnodar, Russian Federation, \\ e-mail: wadimhaikow@inbox.ru, \\ ORCID iD: (iDhttp://orcid.org/0000-0003-1433-3562
}

DOI: 10.5937/vojtehg67-20258; https://doi.org/10.5937/vojtehg67-20258

\author{
FIELD: Applied Mathematics (Ballistics, Theory of Shooting) \\ ARTICLE TYPE: Original Scientific Paper \\ ARTICLE LANGUAGE: English
}

\begin{abstract}
:
A comparison of two groups of plane shooting targets (PSTs) characterizing the shooter-silhouette in different observation and rifle-firing positions was the starting point for this study. Selected infantry targets are used for shooting training in the Russian Federation and in the Swiss Confederation. The comparison results of two target groups (five PSTs in each of them) showed a significant similarity of their geometric shapes. To explain this fact, a targets design system (TDS) was developed. The TDS is based on attributing a certain number of simple geometric shapes geometric primitives (GP). In our case, the number of GPs was equal to ten (five polygons for Russian and five polygons for Swiss targets). The TDS enabled building a human-like target silhouette. If two sides of two adjoining GPs or their parts become common for them, then such GPs can be combined into one common geometric figure whose area is equal to the sum of the two GPs. The TDS was further transformed into two isomorphic graphs. Their adjacency matrix (AM) was obtained. The AM matrices for the Russian PSTs and the Swiss PSTs were the same. To improve the estimation of the area and the coordinates of the target centroid, a matrix modification of Bourke's formulas were proposed. The geometric areas for the Russian and Swiss PSTs and the location of their centroids were refined and compared. GNU Octave, GeoGebra and Mathcad were used as mathematical software for computer calculations and for graphic visualizations.
\end{abstract}

Key words: shooting target, geometric primitive, graph, adjacency matrix, centroid of a polygon, Octave, GeoGebra, Mathcad. 


\section{Introduction}

An infantry shooting target is an object at which marksmen aim and shoot during shooting practice and owing to which shooting performance effectiveness is analyzed (Khaikov, 2018), (Khaikov, 2019). Usually, paper, cardboard, wood-based panels, plastic materials or metal plates are the basic materials for manufacturing two-dimensional or plane shooting targets. It is common that military shooting training with small arms is still conducted with human-like shaped targets, which imitate rival shooters as part of enemy's manpower.

The process of transformation of a three-dimensional moving combatant's figure into a two-dimensional plane silhouette, which is used now as a target, had various national and cultural traits in different armies of the world, but a common feature of the shape extraction phenomenon was the simplification of the outer contour of a shooter and its replacement with some abstract form. In the Soviet Army, schematized (polygon-like) silhouettes of shooting targets were enacted in the shooting training course of the 1969 year (MoD USSR ${ }^{1}$, 1969). Such PSTs were used (without or with some modifications) in the Armed Forces of the Warsaw Pact.

From a geometric point of view, targets of the Swiss Confederation (cibles de campagne) are close to the shapes of Soviet/Russian military $\mathrm{PSTs}^{2}$. In the shooting training literature, there is also evidence of the targets sizes and their areas, but the generalized rules for constructing the geometric contours of a human's silhouette have not been disclosed. There is no systematic data on the coordinates of the geometric centers (centroids) for each of PSTs.

The aim of this paper is to reveal the construction principles and to analyse the geometry of two groups of PSTs representing silhouettes of the opposing force shooters. The main objectives of the research are the development of variants of target geometric description as polygons and the estimation of the target centroids coordinates and the target area using computer mathematics. GNU Octave, the interactive geometry software GeoGebra and the computer algebra system Mathcad are used to solve these sets of tasks.

\footnotetext{
${ }_{2}^{1}$ MoD USSR stands for the Ministry of Defense of the USSR.

2 maybe vice versa because the article states the geometric similarity of target's forms, but does not explore the historical priority of their appearance.
} 


\section{Principles of the PSTs construction}

The shooting target design process for combatant silhouettes has not been explained in scientific literature. Therefore, eliminating such a gap and explaining these rules from the point of view of planimetrics is a needful and urgent objective.

The set of human-like silhouettes (Fig. 1) consists of five different Soviet/Russian ${ }^{3}$ targets with numbers 5, 5a, 6, 7 and 8 (Tarchishnikov, 2011) and, respectively, five Swiss cibles de campagne with the notations K, H, G, F, E (Shooting target, 2018). Below we give an interpretation of the silhouettes, which will be useful for their deeper understanding.

Table 1 shows target designations in English, Russian, German, and French. The attention should be paid to the target denominations used in the Armed Forces of the GDR ${ }^{4}$ (MoD GDR, 1984). For example, the torso target (target No. 7) was called the shooter shooting from the kneeling position, and the man-sized figure (target No. 8) was named the running shooter.

Table 1 - Four language -interpretations of the PSTs names

Таблица 1 - Интерпретации названий плоских стрелковых мишеней на 4-х языках Табела 1 - Називи ДМГ на четири језика

\begin{tabular}{|c|c|c|c|c|}
\hline Types & English & Russian & German & French \\
\hline Target 5 & The head target & $\begin{array}{c}\text { Головная } \\
\text { фигура }\end{array}$ & Beobachter & $\begin{array}{c}\text { Silhouette } \\
\text { tête }\end{array}$ \\
\hline Target 5a & $\begin{array}{c}\text { The head and } \\
\text { shoulders target }\end{array}$ & Голова и плечи & $\begin{array}{c}\text { Eingegrabener } \\
\text { Schutze }\end{array}$ & $\begin{array}{c}\text { Tête et } \\
\text { épaules }\end{array}$ \\
\hline Target 6 & $\begin{array}{c}\text { The chest / } \\
\text { upper torso } \\
\text { target }\end{array}$ & Грудная фигура & $\begin{array}{c}\text { Ligender } \\
\text { Schutze }\end{array}$ & $\begin{array}{c}\text { Silhouette } \\
\text { buste }\end{array}$ \\
\hline Target 7 & The torso target & Поясная фригура & $\begin{array}{c}\text { Kniender } \\
\text { Schutze }\end{array}$ & $\begin{array}{c}\text { Silhouette à } \\
\text { genou }\end{array}$ \\
\hline Target 8 & $\begin{array}{c}\text { Man sized / full } \\
\text { sized target }\end{array}$ & $\begin{array}{c}\text { Ростовая } \\
\text { фигура }\end{array}$ & $\begin{array}{c}\text { Laufender } \\
\text { Schutze }\end{array}$ & $\begin{array}{c}\text { Silhouette } \\
\text { mannequin }\end{array}$ \\
\hline
\end{tabular}

A set of $\mathrm{X}$ - and $\mathrm{Y}$-projections in the Cartesians system is usually used for describing plane targets. The performed analysis of the geometry of all ten targets shows that they are polygons whose vertices are connected by straight lines. The designations of the targets and their

${ }^{3}$ The notation S/R will be used in the tables for Soviet/Russian shorter writing.

${ }^{4}$ GDR stands for the German Democratic Republic. 
geometrical dimensions in centimeters are shown in Fig. 1. The cibles de campagne were partially analyzed in the paper (Khaikov, 2019). It would also be interesting to know that the Armed Forces of the Polish People's Republic (PPR) developed their own PSTs entitled figury bojowe (pol.) (MoD PPR, 1977).
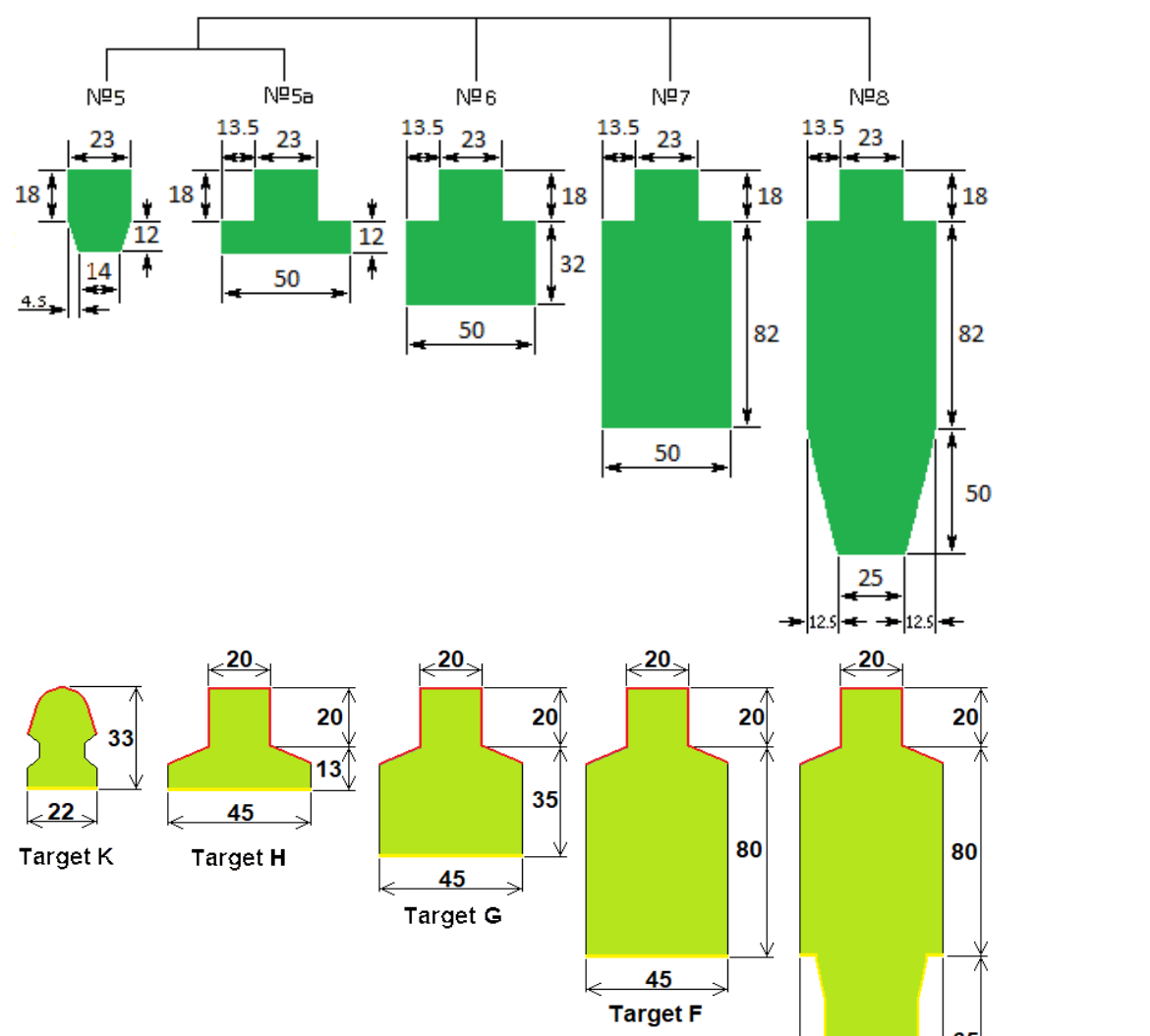

20

Target E

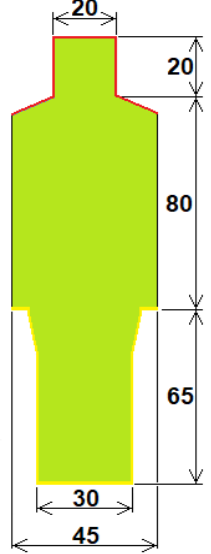

Figure 1 - Silhouettes of five Soviet/Russian PSTs (top row) and five Swiss shooting targets (cibles de campagne) (bottom row)

Pис. 1 - Пять советских / российских плоских мишеней (верхний ряд) и пять швейцарских мишеней (нижний ряд)

Слика 1 - Силуете пет совјетских/руских ДМГ (горњи ред) и пет швајцарских мета за гађање (доњи ред) 
The geometric study shows that the Soviet/Russian and Swiss infantry targets are based on geometric primitives i.e. plane figures of an elementary form: triangles, rectangles and trapeziums. The silhouette design of PSTs is based on the following rules:

(1) The principle of simplifying the original complex form is the basis for the construction of infantry shooting targets. A complex silhouette is reproduced by merging into a coherent whole more simple GP;

(2) The silhouette of a PST is a plane figure, all vertices of which are interconnected by first order lines. By connecting the vertices with twoorder or more order curves, it is possible to enhance the visual effect of target perception (for example, the Swiss target K);

(3) PSTs, being geometric shapes, are usually symmetric along the vertical axis OY.

PST No. $5 a$ «head» is composed of a rectangle and an isosceles trapezoid, a large base of which is joined to the base of the rectangle. In all subsequent constructions, the "head» as a polygon acts as an independently functioning geometric primitive. For PST No. 5, the GP "shoulder» consists of a rectangle and a right-angled triangle. The right and left «shoulders» of PST No. 5 are symmetrical. In turn, figure No. 5 is a more difficult geometric primitive for PSTs No. 6-8. Based on this, we formulate the 4-th rule: «A more complex PST shape is built on the principle of merging a new geometric primitive with the shape that was formed on the previous step». Thus, targets No. 5a, 5-8 can be represented as a combination of the following five geometric primitives: «head», "shoulders (left / right)», "bottom of the chest», "bottom of the torso» and «legs». The GPs for Soviet/Russian targets are listed from left to right in Fig. 2a. The GPs for Swiss targets are represented in Fig. $2 b$. All dimensions in Fig. 2 are indicated in centimeters.

The figure "head $»^{5}$ (it is target No. 5 , made of simpler shapes) for subsequent figures is also considered to be a geometric primitive. By merging it with the "shoulders» primitives ${ }^{6}$, we obtain target No. 5 (or the Swiss target $\mathrm{H}$ ). Further, by merging target No. 5 (we will consider it as the next geometric primitive) with «the bottom of the chest» primitive, we obtain target No. 6 (or the Swiss target G). Targets 7 and 8 (or the Swiss targets $F$ and $E$ ) are made by the same rule of merging.

${ }^{5}$ geometric primitive «head» (Fig. $2 b$ ) was modified relative to the original Swiss target K. ${ }^{6}$ left and right shoulders. 


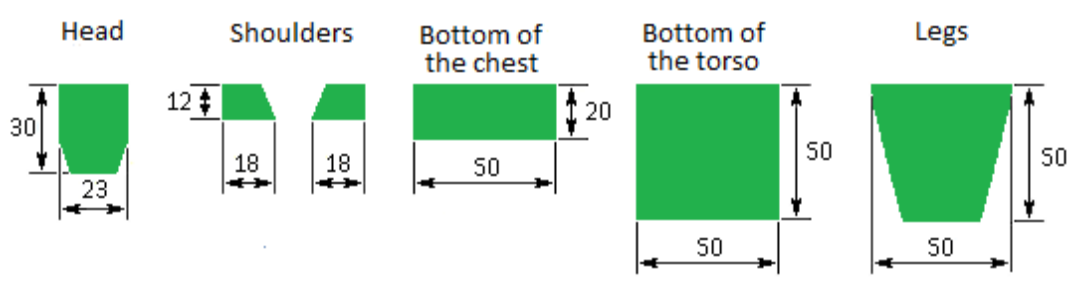

a)
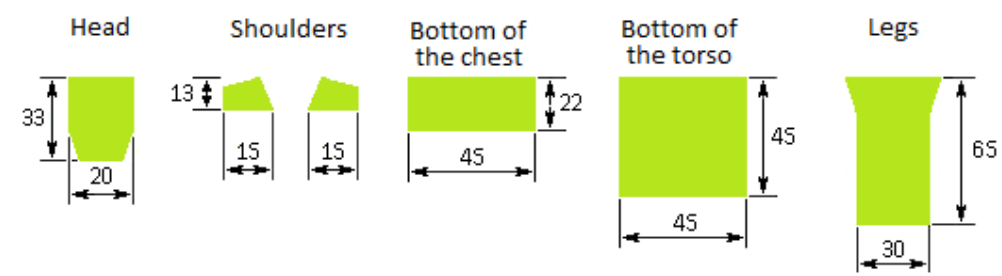

b)

Figure 2 - Geometric primitives as constituent elements of PSTs a) Soviet / Russian targets; b) Swiss targets;

Puc. 2 - Геометрические примитивы как составляющие а) советских / российских мишеней; $\quad$ b) швейцарских мишеней;

Слика 2 - Основне геометријске фригре као конститутивни елементи ДМГ а) совјетских/руских мета; b) швајцарских мета

The comparative characteristics of the areas of the Soviet/Russian and the Swiss geometric primitives are illustrated in Table 2 (all dimensions - in square centimeters).

Table 2 - Comparative characteristic of the areas of GPs (square centimeters) Таблица 2 - Сравнительная характеристика площадей ГП (кв. сантиметры)

Табела 2 - Поређење карактеристика површина ОГФ у квадратним центиметрима

\begin{tabular}{|l|c|c|c|c|c|}
\hline Types & Head & Shoulders & $\begin{array}{c}\text { Bottom of } \\
\text { the chest }\end{array}$ & $\begin{array}{c}\text { Bottom of } \\
\text { the torso }\end{array}$ & Legs \\
\hline A - areas of S/R GPs & 636 & $2 * 189=378$ & 1000 & 2500 & 1875 \\
\hline B - areas of Swiss GPs & 614.5 & $2 * 154=308$ & 990 & 2025 & 1988 \\
\hline $100-\left(100^{*}\right.$ B/A) ratio, \% & 3.4 & 18.5 & 1 & 19 & -6 \\
\hline
\end{tabular}

From the data collected in Table 2, it can be seen that the GPs («head», "shoulders», "bottom of the chest», "bottom of the torso») of the Soviet/Russian targets are 1-19\% bigger than the GPs of the Swiss 
targets; however, the area of the Swiss GP «legs» are larger $(6 \%)$ than the corresponding Soviet/Russian one.

The principle of sequential merging of geometric primitives and the formation of PSTs Nos. 5, 5a, 6-8 are shown in Fig. 3. At the top in the yellow rectangle, there are five GPs used in the merging process, and below, in a blue rectangle, there are five PSTs silhouettes formed from them.

The quantity of arrows at the bottom of the yellow rectangle (near numbers 0-4) shows the quantity of GPs which were used to build all five PSTs. The quantity of arrows at the top of the blue rectangle (near numbers 5-9) shows the quantity of the geometric primitives-components that were used to build an appropriate silhouette.

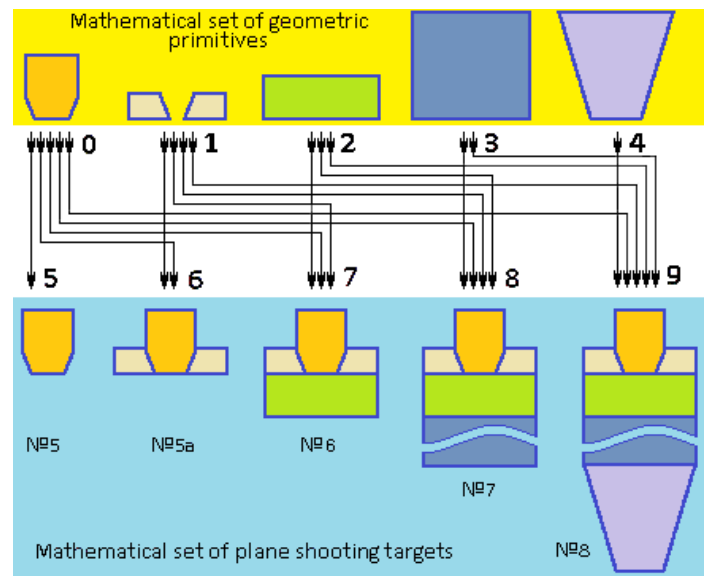

Figure 3 - The implementation of the principle of consistently combining geometric primitives into target silhouettes (the shooting targets design system)

Pис. 3 - Реализация принципа последовательного объединения геометрических примитивов в силуэты стрелковых мишеней (система порождения мишеней) Слика 3 - Примена принципа конзистентног комбиновања основних геометријских фигура у силуете мета (систем пројектовања мета за гађање)

The construction of a PST silhouette can be compared with a mosaic puzzle. Each puzzle piece has a different shape. Mosaic elements in this task correspond to geometric primitives and the result of their conjunction (merging) will match the external contour of the target silhouette (see Fig. 3). When we attempt to place a puzzle piece in its place, it will only fit if it is placed properly in the correct location of the considered shooting target. In order to get the correct silhouette of target No. 8, not only is it necessary to use the six «mosaic elements», but also 
to place them in a correct order. The structure such of Fig. 3 was named the target design system (TDS). The TDS consists of GPs (top row on a the yellow background) and PSTs (bottom row) that can be built from them. The TDS of Fig. 3 illustrates the formation of Soviet/Russian PSTs; however, this scheme can be used to explain the principle of the construction of Swiss PSTs.

If the GPs of Fig. 3 are numbered from 0 to 4, and the PSTs from 5 to 9 , then the TDS can be transformed into a directed graph that has 10 (from 0 to 9 ) vertices (5 GPs +5 targets) and 15 edges $^{7}$ (Fig. 4 a, b). Two graphs of Fig. $4 a, b^{8}$ are isomorphic. Since the graph had 10 vertices thus the adjacency matrix (AM) $\boldsymbol{A}$ has a size of $10 \times 10$. Its 100 elements are presented in Fig. $4 c$ :

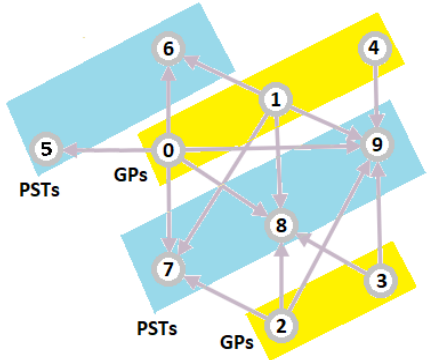

a)

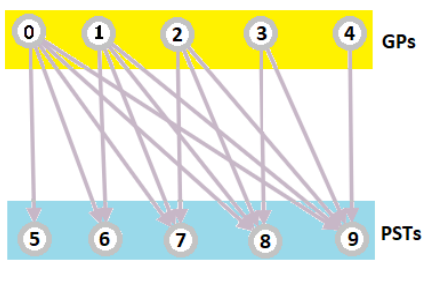

b)

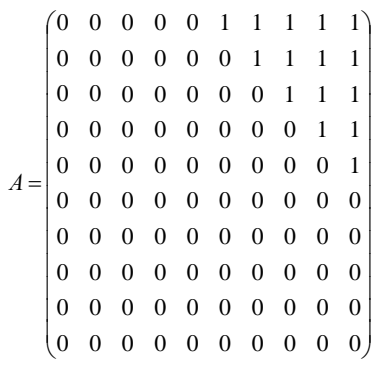

c)

Figure 4 - Directed graphs $(a, b)$ and graph adjacency matrix or the connection matrix (c) Puc. 4 - Направленные графры (a, b) и их матрица смежности (c)

Слика 4 - Усмерени графрови (a, b) и матрица повезаности графа (c)

The received AM (Fig. 4c) is a sparse matrix because it contains only 15 nonzero elements and 85 zero-elements. The matrix sparsity is $85 \%$, and the matrix density $-15 \%$. All nonzero-valued elements form a special upper triangular matrix with four diagonals that are parallel to the main diagonal. The AM is singular, since its determinant is 0 . It should be noted that the AMs for Soviet/Russian and Swiss PSTs are the same.

The bipartite graph of Fig. $4 b$ is a graph whose vertices are divided into two disjoint and independent sets of GPs / PSTs such that every edge connects a vertex in GPs to one in PSTs.

\footnotetext{
${ }^{7}$ The edge is a connection between two vertices.

${ }^{8}$ Graphs of Fig. $4 a, 4 b$ were built by using Internet-application http://graphonline.ru .
} 


\section{Geometric specification of PSTs}

The main way of the geometric description of PST silhouettes is recreating them by the projections of the sides on the $X$ and $Y$ axes of the Cartesian coordinate system. But for describing the target contour, three more ways can be used:

1. Representation of the PST by the coordinates of the vertices of the polygon that describes the silhouette. The shape-forming matrix consists of two columns: the first column contains the coordinates of the abscissas, and the second - the coordinates of the ordinates.

The coordinates of the six vertices of target $5 a$ (left matrix) and the modified "head» primitive (right matrix) written in the form of a Mathcadmatrix are shown below. These are rectangular matrices, each row of which contains the $X$ and $Y$ coordinates $(\mathrm{cm})$ of the corresponding vertex of the polygon, while the seventh row repeats the first vertex coordinates and makes the contour of the target closed:

$$
T 1:=\left[\begin{array}{cc}
18 & 0 \\
32 & 0 \\
36.5 & 12 \\
36.5 & 30 \\
13.5 & 30 \\
13.5 & 12 \\
18 & 0
\end{array}\right]
$$$$
T 2:=\left[\begin{array}{cc}
16 & 0 \\
29 & 0 \\
32.5 & 13 \\
32.5 & 33 \\
12.5 & 33 \\
12.5 & 13 \\
16 & 0
\end{array}\right]
$$

Using the Cartesian coordinate system, Fig. 5a illustrates the increase in the height of Soviet/Russian PSTs if every new GP is included in the target composition. All geometrical dimensions of Fig. $5 \mathrm{a}$ are in centimeters. The image was obtained using GNU Octave software.

2. The target silhouette can be described by a set vector magnitudes and direction angles relative to the previous one Fig. $5 b$. The geometrical dimensions of Fig. $5 b$ are in millimeters. The vertices of the targets (as plane polygons) are designated as $\mathrm{A} 1, \mathrm{~A} 2, \ldots \mathrm{Ai}$. The angles between the sides (or edges) of both polygons (Fig. $5 b$ ) are in degrees. The dashed line in Fig. $5 b$ (right fragment) shows the connection boundary of the GP «head» with the primitive «shoulders».

3. The silhouette description using analytical equations of the sides of the polygon with an indication of their boundaries (start/end points). 
For method No. 2, the vector magnitudes and the direction angles can be replaced by the coordinates of the vector in the Cartesian coordinate system (XOY).
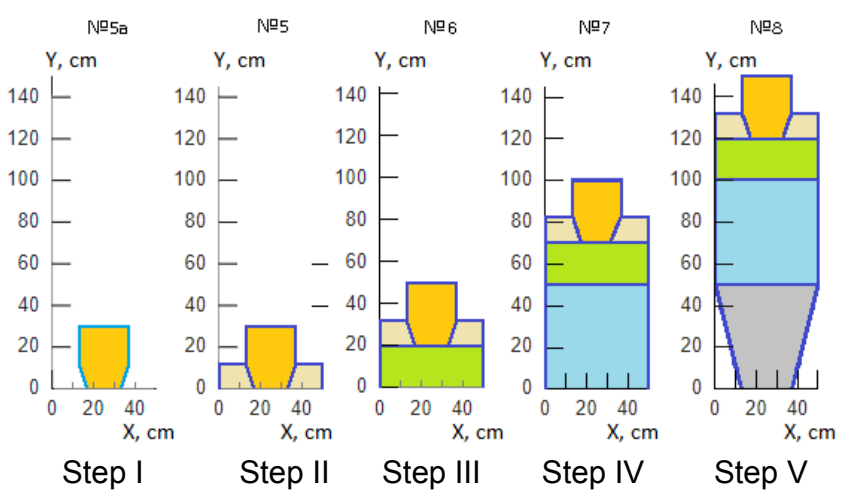

Step III

Step V
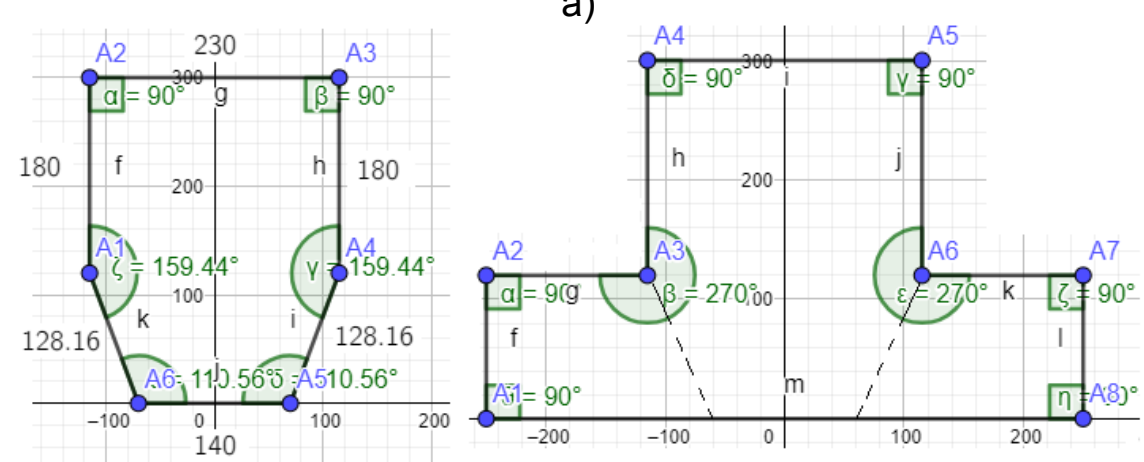

b)

Figure 5 - Increase of the height of shooting targets relative to each other (a) and their structure (b)

Puс. 5 - Увеличение высоты стрелковых мишеней относительно друг друга (a) и структура мишеней (b)

Слика 5 - Повећање висина мета за гађање у међусобном односу (а) као и у односу на њихову структуру (b)

For a shooter, the necessary a priori information about a target is: the target size (the maximum width and the maximum height); the target area, and the coordinates (abscissa and ordinate) of the target centroid ${ }^{9}$.

\footnotetext{
${ }^{9}$ The centroid of a polygon is also known as the «center of gravity» or the «center of mass».
} 
The geometrical dimensions and the description of PSTs can be found in shooting reference books, for example (Tarchishnikov, 2011, pp.118-120), (MoD GDR, 1984), (MoD PPR, 1977).

Shoelace formula (or Gauss's area formula) is a mathematical tool for estimating the PST area like a geometric polygon. If the numbering of the vertices of the polygon is counterclockwise, then its area $A$ can be calculated (Bourke, 1988):

$$
\mathrm{A}=\frac{1}{2} \sum_{i=0}^{N-1}\left(x_{i} y_{i+1}-x_{i+1} y_{i}\right)
$$

where $N$ is the number of vertices of the polygon.

Since the determinant of a $2 \times 2$ matrix $B\left(b_{11}=a ; b_{12}=b ; b_{21}=c ; b_{22}=d\right)$ is

$$
|B|=\operatorname{det}(B)=\left|\begin{array}{ll}
a & b \\
c & d
\end{array}\right|=a d-b c .
$$

Expression (1) can be modified

$$
\mathrm{A}=\frac{1}{2} \sum_{i=0}^{N-1}\left|\begin{array}{cc}
x_{i} & y_{i} \\
x_{i+1} & y_{i+1}
\end{array}\right|
$$

but in (Wolfram MathWorld, 2018) the area's formula is given based on the sum of determinants (det)

$$
\mathrm{A}=\frac{1}{2}\left(\left|\begin{array}{ll}
x_{0} & x_{1} \\
y_{0} & y_{1}
\end{array}\right|+\left|\begin{array}{ll}
x_{1} & x_{2} \\
y_{1} & y_{2}
\end{array}\right|+\ldots+\left|\begin{array}{cc}
x_{N-1} & x_{0} \\
y_{N-1} & y_{0}
\end{array}\right|\right)=\frac{1}{2} \sum_{i=0}^{N-1}\left|\begin{array}{ll}
x_{i} & x_{i+1} \\
y_{i} & y_{i+1}
\end{array}\right|
$$

but, since

$$
|B|=\left|\begin{array}{ll}
a & b \\
c & d
\end{array}\right|=\left|\begin{array}{ll}
a & b \\
c & d
\end{array}\right|^{T}=\left|\begin{array}{ll}
a & c \\
b & d
\end{array}\right|=\left|\begin{array}{ll}
d & b \\
c & a
\end{array}\right|=\left|\begin{array}{ll}
d & c \\
b & a
\end{array}\right|
$$

we repeat expression (2). Therefore, the transformed Bourke's formula (2) and the expression from (Wolfram MathWorld, 2018) (3) coincided. 
The resulting formula (2) is more convenient, since it corresponds to the matrix of the coordinates that describe the vertices of the polygon. If the vertices of the polygon are numbered not counterclockwise, but vice versa, then this imperfection can be eliminated in two ways:

(1) vertical flip of the matrix; in the computer software Mathcad, this can be implemented using the vertflip( $M)$ command; A).

(2) by using the absolute value of $A$ (the modulus of a real number

In order to calculate the polygon's area by using formulas $(1,2)$, it is necessary to know the number of vertices of the polygon $(\mathrm{N})$; then, for the considered targets, we will collect them in Table 3.

Table 3 - Comparative characteristics of the number of vertices for PSTs

Таблица 3 - Сравнительная характеристика количества вершин для мишеней Табела 3 - Упоредне карактеристике броја врхова ДМГ

\begin{tabular}{|l|c|c|c|c|c|}
\hline Types & $\begin{array}{c}\text { Head } \\
\text { target }\end{array}$ & $\begin{array}{c}\text { Head and } \\
\text { shoulders }\end{array}$ & $\begin{array}{c}\text { Upper } \\
\text { torso } \\
\text { target }\end{array}$ & $\begin{array}{c}\text { Torso } \\
\text { target }\end{array}$ & $\begin{array}{c}\text { Full } \\
\text { sized } \\
\text { target }\end{array}$ \\
\hline Number of vertices for S/R PSTs & 6 & 8 & 8 & 8 & 10 \\
\hline Number of vertices for Swiss PSTs & 6 & 8 & 8 & 8 & 14 \\
\hline
\end{tabular}

Table 3 shows that the result of comparing the $\mathrm{N}$ numbers for Soviet/ Russian and Swiss targets shows the similarity of these two groups of PSTs. The minimum number of vertices is six, and the maximum is fourteen.

Using formulas (1) and (2), we estimate the area of the Soviet/ Russian and Swiss targets. The resulting data are combined in Table 4. The areas of all Soviet/Russian targets are bigger by 3.4-12.8 percent than the corresponding areas of the Swiss targets.

Table 4 - Comparative characteristics of the PST areas

Таблица 4 - Сравнительная характеристика площадей стрелковых мишеней

Табела 4 - Упоредне карактеристике површина ДМГ

\begin{tabular}{|l|c|c|c|c|c|}
\hline Types & $\begin{array}{c}\text { Head } \\
\text { target }\end{array}$ & $\begin{array}{c}\text { Head and } \\
\text { shoulders }\end{array}$ & $\begin{array}{c}\text { Upper } \\
\text { torso } \\
\text { target }\end{array}$ & $\begin{array}{c}\text { Torso } \\
\text { target }\end{array}$ & $\begin{array}{c}\text { Full sized } \\
\text { target }\end{array}$ \\
\hline A1 - areas of S/R PSTs, $\mathrm{cm}^{2}$ & 636 & 1014 & 2014 & 4514 & 6389 \\
\hline A2 - areas of Swiss PSTs, $\mathrm{cm}^{2}$ & 614.5 & 922.5 & 1913 & 3938 & 5925 \\
\hline $100-\left(100^{*} \mathrm{~A} 2 / \mathrm{A} 1\right)$ ratio, $\%$ & 3.4 & 9.0 & 5.0 & 12.8 & 7.3 \\
\hline
\end{tabular}


The ratio of areas of geometric primitives in the total area of four targets for the group of Soviet/Russian targets is shown in Fig. 6. White color indicates the area of the GP «head»; orange color corresponds to the area of primitive "shoulders»; dark blue is "bottom of the chest»; blue specifies, "bottom of the torso»; and purple means «legs». As the shape of a PST becomes more complex, the area of each part of the GP set is decreased. The target "head» is absent since only one GP is used for its formation.
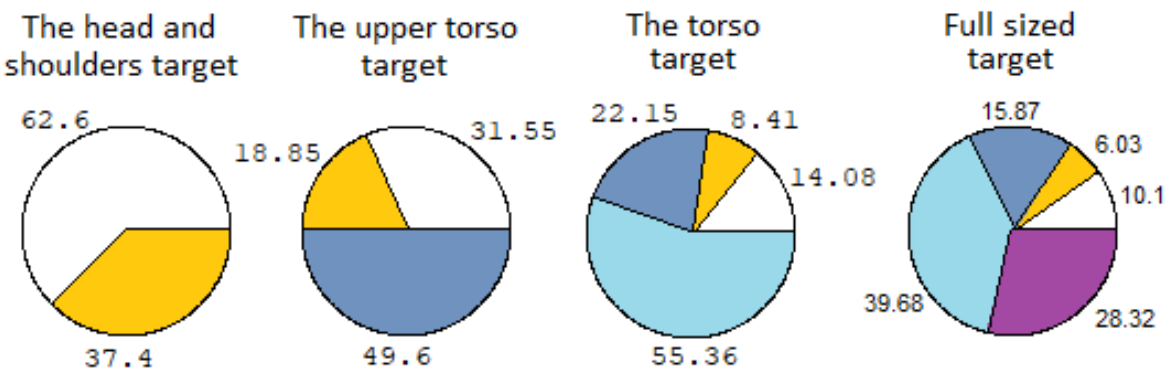

Figure 6 - The proportion of GP areas in the total area of PSTs

Puс. 6 - Доля площади геометрических примитивов в общей площади стрелковых мишеней

Слика 6 - Удео површина ОГФ у укупној површини ДМГ

Another kind of Bourke's equations (Bourke, 1988) can be used for estimating the coordinates of the polygon centroid:

$$
\begin{aligned}
& \mathrm{C}_{\mathrm{x}}=\frac{1}{6 A} \sum_{i=0}^{N-1}\left(x_{i}+x_{i+1}\right)\left(x_{i} y_{i+1}-x_{i+1} y_{i}\right), \\
& \mathrm{C}_{\mathrm{y}}=\frac{1}{6 A} \sum_{i=0}^{N-1}\left(y_{i}+y_{i+1}\right)\left(x_{i} y_{i+1}-x_{i+1} y_{i}\right),
\end{aligned}
$$

where $N$ is the number of vertices of the polygon.

Applying to $(4,5)$ an expression for the $2 \times 2$ determinant $(|A|$ or $\operatorname{det}(\mathrm{A}))$, we modify these formulas

$$
\mathrm{C}_{\mathrm{x}}=\frac{1}{6 A} \sum_{i=0}^{N-1}\left[\left|\begin{array}{cc}
x_{i} & -1 \\
x_{i+1} & 1
\end{array}\right| \cdot\left|\begin{array}{cc}
x_{i} & y_{i} \\
x_{i+1} & y_{i+1}
\end{array}\right|\right],
$$




$$
\mathrm{C}_{\mathrm{y}}=\frac{1}{6 A} \sum_{i=0}^{N-1}\left[\left|\begin{array}{cc}
y_{i} & -1 \\
y_{i+1} & 1
\end{array}\right| \cdot\left|\begin{array}{cc}
x_{i} & y_{i} \\
x_{i+1} & y_{i+1}
\end{array}\right|\right] .
$$

For such interpretation, the area of the polygon is the sum of the $2 \times 2$ determinants, and the abscissa and the ordinate of the centroid are their product. Thus, the formulas for the area and the coordinates of the polygon centroid now have a matrix form.

We calculate the centroid coordinates of the Soviet/Russian PSTs and compare them with the corresponding coordinates of the centroids of the Swiss targets. The results of the comparison are given in Table 5.

Table 5-Comparative characteristic of the coordinates of PST centroids

Таблица 5 - Сравнительная характеристика координат центроидов стрелковых мишеней

Табела 5 - Упоредне карактеристике координата центроида ДМГ

\begin{tabular}{|l|c|c|c|c|c|}
\hline Types & $\begin{array}{c}\text { Head } \\
\text { target }\end{array}$ & $\begin{array}{c}\text { Head and } \\
\text { shoulders }\end{array}$ & $\begin{array}{c}\text { Upper } \\
\text { torso } \\
\text { target }\end{array}$ & $\begin{array}{c}\text { Torso } \\
\text { target }\end{array}$ & $\begin{array}{c}\text { Full sized } \\
\text { target }\end{array}$ \\
\hline $\mathrm{C}_{\mathrm{x}}$ of S/R PSTs, cm & 25 & 25 & 25 & 25 & 25 \\
\hline $\mathrm{C}_{\mathrm{y}}$ of S/R PSTs, cm & 15.9 & 12.1 & 21.1 & 45.6 & 75.7 \\
\hline $\mathrm{C}_{\mathrm{x}}$ of Swiss PSTs, cm & 22.5 & 22.5 & 22.5 & 22.5 & 22.5 \\
\hline $\mathrm{C}_{\mathrm{y}}$ of Swiss PSTs, cm & 17.4 & 13.3 & 22.7 & 44.5 & 83.8 \\
\hline $100 \cdot \mathrm{C}_{\mathrm{y}} / \mathrm{H}_{\max }$ for S/R & $53 \%$ & $40.3 \%$ & $42.2 \%$ & $45.6 \%$ & $50.4 \%$ \\
\hline $100 \cdot \mathrm{C}_{\mathrm{y}} / \mathrm{H}_{\max }$ for Swiss & $52.7 \%$ & $40.3 \%$ & $41.2 \%$ & $44.5 \%$ & $50.8 \%$ \\
\hline
\end{tabular}

The value of $100 \cdot \mathrm{C}_{\mathrm{y}} / \mathrm{H}_{\max }$ shows the location of the centroid $Y$ coordinate relative to the PST height. The ratio of these parameters for targets such as «head», "head and shoulders» and "full sized target» for Soviet/Russian and Swiss targets is less than one percent. For the «upper torso target» and "torso target» targets its 2.2 and 2.4 percent. The X-coordinate of the centroid lies on the axis of symmetry $(22.5 \mathrm{~cm}$ for Swiss PSTs and $25 \mathrm{~cm}$ for Soviet/Russian targets).

\section{Conclusions}

Planimetrics and graph theory allowed us to formulate a general construction principle for analysing Soviet/Russian and Swiss PSTs, which is based on the use five similar in geometry GPs. To compare different groups of infantry targets, a TDS was proposed that consists of geometric primitives set; directed lines between GPs and obtained 
infantry targets. The TDS can be represented as a graph or an adjacency matrix.

Investigated by us two target groups had the same directed graphs and, therefore, an equal adjacency matrix. This matrix refers to the type of sparse matrix and has the following characteristics: dimension: $10 \times 10$ (15 nonzero elements and 85 zero-elements); matrix sparsity is $85 \%$, and matrix density $-15 \%$.

For formulas which determining of an area and centroid coordinates of polygons we propose their matrix forms. These kinds of expressions are more convenient by combining information about polygon vertices coordinates in a matrix with $n \times 2$ dimension.

Comparison of Soviet/Russian and Swiss PSTs showed that areas of all Soviet/Russian targets are more by $3.4-12.8 \%$ than the corresponding area of Swiss targets. The exception to this rule relates to the ratio of the areas of «man sized» targets. Due to the fact that all targets have an vertical axis of symmetry, the X-coordinate of a target centroid depends on location its abscissa. The $\mathrm{Y}$-coordinate of a centroid was compared with a height of the target. The maximum offset of the $Y$ coordinate of centroids for Soviet/Russian targets relative Swiss targets was $2.4 \%$. Thus, the similarity of the geometry of two reviewed groups of PSTs is explained by the resemblance of a formation mechanism, the uniformity of the mathematical graph (adjacency matrix) and identified geometric primitives. The results of this study can be extended to other PSTs groups.

\section{References}

Bourke, P. 2018. Calculating the area and centroid of a polygon. Available at:https://www.seas.upenn.edu/ sys502/extra_materials/Polygon\%20Area\%20a nd\%20Centroid.pdf. Accessed: 03.12.2018.

Khaikov, V.L. 2018. Single shot hit probability estimation as a result of a numerical solution of double integrals using Mathcad. Vojnotehnički glasnik/Military Technical Courier, 66(4), pp.739-756. Available at: https://doi.org/10.5937/vojtehg66-17433.

Khaikov, V.L. 2019. Assessment of the single shot hit probability as a function of the horizontal range taking into account different target types and points of aim. Vojnotehnički glasnik/Military Technical Courier, 67(1), pp.13-35. Available at: https://doi.org/10.5937/vojtehg67-18522.

-Ministry of Defense of the GDR. 1984. Zieldarstellung K 310/3/002. Berlin: NVA Landstreitkraftte (in German).

-Ministry of Defense of the PPR. 1977. Album Tarcz i figur bojowych. Warszawa: Wydawnictwo Ministerstwa Obrony Narodowej (in Polish). 
-Ministry of Defense of the USSR. 1969. Kurs strel'b iz strelkovogo oruzhiya. Moscow: Voyennoye izdatel'stvo (in Russian). (In the original: MO СССР. 1969. Курс стрельб из стрелкового оружия. Москва: Военное издательство).

Shooting target. 2018. Wikipedia. Available at: https://en.wikipedia.org/wiki/Shooting_target. Accessed: 03.12.2018.

Tarchishnikov, A.A. 2011. Kurs strel'b. Minsk: Belorusskiy natsional'nyy tekhnicheskiy universitet (in Russian). (In the original: Тарчишников, А.A. 2011. Курс стрельб. Минск: Белорусский национальный технический университет).

Wolfram MathWorld. 2018. Polygon Area. [Internet]. Available at: http://mathworld.wolfram.com/PolygonArea.html. Accessed: 03.12.2018.

АНАЛИЗ ДВУХ ГРУПП ПЛОСКИХ СТРЕЛКОВЫХ МИШЕНЕЙ КАК СОВОКУПНОСТЕЙ ГЕОМЕТРИЧЕСКИХ ПРИМИТИВОВ

Вадим Л. Хайков,

независимый исследователь, г. Краснодар, Российская Федерация

РУБРИКИ: 78.21.00 Военно-прикладные науки;

78.21.47 Баллистика. Теория стрельбы

ВИД СТАТЬИ: оригинальная научная статья

ЯЗЫК СТАТЬИ: английский

Резюме:

Сравнение двух групп стрелковых мишеней, которые характеризуют силуэт стрелка в различных его положениях при ведении наблюдения и стрельбе, стало отправной точкой для начала исследования. Выбранные для рассмотрения мишени используются в процессе стрелковой подготовки в Российской Федерации и в Швейцарской Конфедерации. Результат сравнения двух групп мишеней (по пять мишеней в каждой группе) показал межгрупповое сходство их геометрических фрорм. Для объяснения этого фракта, была разработана система построения мишеней (СПМ). Она основана на выделении некоторого количества простых геометрических фигур во множество так называемых геометрических примитивов (ГП) с дальнейшим конструированием мишеней на их основе. В нашем случае общее количество ГП пять в каждой рассматриваемой группе. Принцип объединения ГП состоит в том, что если две стороны двух смежных примитивов или их части являются общими для них обоих, то такие ГП объединяются в одну общую геометрическую фригуру, площадь которой равна сумме их площадей. Далее СПМ была преобразована в два изоморфных графра, которые позднее были трансформированы в матрицы смежности. Такие матрицы для российских и швейцарских мишеней оказались равными. Для 
улучшения оценки площади и координат центроида стрелковой мишени как плоского многоугольника была предложена матричная модифрикация формул Берка (Bourke). B результате uх использования были уточнены значения геометрических площадей для российских и швейцарских мишеней и значения координат их центроидов. B качестве математического программного обеспечения для реализации компьютерных расчётов $и$ графической визуализации результатов построений были использованы GNU Octave, GeoGebra u Mathcad.

Ключевые слова: стрелковая мишень, геометрический примитив, математический граф, матрица смежности, центроид многоугольника, Octave, GeoGebra, Mathcad.

АНАЛИЗА ДВЕ ГРУПЕ ДВОДИМЕНЗИОНАЛНИХ ПЕШАДИЈСКИХ МЕТА КАО СКУПОВА ОСНОВНИХ ГЕОМЕТРИЈСКИХ ФИГУРА

Вадим Л. Хајков

независни истраживач, Краснодар, Руска Федерација

ОБЛАСТ: примењена математика (балистика, теорија гађања)

ВРСТА ЧЛАНКА: оригинални научни рад

ЈЕЗИК ЧЛАНКА: енглески

\section{Сажетак:}

Ова студија пореди две групе дводимензионалних мета за гађање (ДМГ) у облику силуете стрелца који пуца из пушке из различитих положаја. Одабране пешадијске мете за гађање користе се за увежбавање гађања у Руској Федерацији и Швајцарској Конфедерацији. Поређење резултата две групе мета (по пет у свакој групи) показује значајну сличност њихових геометријских облика. Да би се објаснила ова чињеница, развијен је систем пројектовања мета (СПМ) заснован на одређеном броју једноставних геометријских облика - основних геометријских фригура (ОГФ). У нашем случају тај број је био десет (пет полигона за руске и пет полигона за швајцарске мете). Користећи СПМ, израђене су мете у облику људских силуета. Ако две странице две суседне ОГФ, или њихови делови, постану заједнички, њиховим комбиновањем добијена ОГФ има површину једнаку укупним повриинама двеју површина суседних ОГФ. Даљом трансформацијом СПМ добијају се два изоморфна графра. Њихове добијене матрице повезаности (МП) биле су исте и за руске и за швајцарске ДМГ. За побољшање естимације површина и координата центроида мета, предложена је модификација матрице Буркеовим формулама. Геометријске површине руских и швајцарских ДМГ, као и локације њихових центроида, прецизно су одређене и упоређене. Математички софтвери коришћени за 
компјутерска израчунавања и визуализацију путем графова били су GNU Octave, GeoGebra u Mathcad.

Кључне речи: мета за гађање, основне геометријске фигуре, графр, матрица повезаности, центроид полигона, Octave, GeoGebra, Mathcad.

Paper received on / Дата получения работы / Датум пријема чланка: 21.01.2019. Manuscript corrections submitted on / Дата получения исправленной версии работы / Датум достављања исправки рукописа: 29.01.2019.

Paper accepted for publishing on / Дата окончательного согласования работы / Датум коначног прихватања чланка за објављивање: 31.01.2019.

(C) 2019 The Author. Published by Vojnotehnički glasnik / Military Technical Courier

(www.vtg.mod.gov.rs, Втг.мо.упр.срб). This article is an open access article distributed under the terms and conditions of the Creative Commons Attribution license

(http://creativecommons.org/licenses/by/3.0/rs/).

(c) 2019 Автор. Опубликовано в «Военно-технический вестник / Vojnotehnički glasnik / Military Technical Courier» (www.vtg.mod.gov.rs, втг.мо.упр.срб). Данная статья в открытом доступе и распространяется в соответствии с лицензией «Creative Commons» (http://creativecommons.org/licenses/by/3.0/rs/).

(c) 2019 Аутор. Објавио Војнотехнички гласник / Vojnotehnički glasnik / Military Technical Courier (www.vtg.mod.gov.rs, втг.мо.упр.срб). Ово је чланак отвореног приступа и дистрибуира се у складу са Creative Commons лиценцом (http://creativecommons.org/licenses/by/3.0/rs/). 